Krishpersad Manohar Dale Ramlakhan Gurmohan Kochhar Subhas Haldar

Dept. of Mechanical and Manufacturing The University of the West Indies St. Augustine, Trinidad, West Indies kmanohar@eng.uwi.tt

\section{Biodegradable Fibrous Thermal Insulation}

This study investigates the potential of naturally occurring biodegradable fibers for use as building thermal insulation. The use of biodegradable building thermal insulation would alleviate the environmental problems presently associated with the disposal of currently used man-made non-biodegradable thermal insulations. The apparent thermal conductivity $(\lambda)$ for biodegradable coconut and sugarcane fiber were investigated in accordance with ASTM C 518 over the density ranges $40 \mathrm{~kg} / \mathrm{m}^{3}$ to $90 \mathrm{~kg} / \mathrm{m}^{3}$ and $70 \mathrm{~kg} / \mathrm{m}^{3}$ to $120 \mathrm{~kg} / \mathrm{m}^{3}$ for the test temperature ranges $13.2^{\circ} \mathrm{C}$ to $21.8^{\circ} \mathrm{C}$ and $18^{\circ} \mathrm{C}$ to $32^{\circ} \mathrm{C}$, respectively. The experimental data were used to determine empirical equations for $\lambda$ variation with density and temperature for both coconut and sugarcane fiber. Comparison of $\lambda$ at $24^{\circ} C$ for coconut and sugarcane fiber were made with seven different conventional insulation from published data. The results indicated that the minimum $\lambda$ for both coconut and sugarcane fiber are within the range normally associated with building thermal insulation. The $\lambda$ variation with density and mean temperature for both coconut and sugarcane fiber were consistent with the behavior of loose-fill thermal insulation. Keywords: Fibrous insulation, building insulation, coconut fiber, sugarcane fiber

\section{Introduction}

In recent years retrofitting, refurbishing, reconstructing and upgrading existing structures has seen a growing volume of discarded insulation for disposal. The man-made non-biodegradable materials are fast filling the landfills and becoming a problem for disposal. This is creating an environmental problem for developing countries which do not have the proper facilities to accommodate or recycle material. Factoring in the environmental issue has turned research towards finding biodegradable environmentally friendly insulation.

The aim of this research is to investigate the potential of indigenous biodegradable fibrous materials (coconut fiber and sugarcane fiber) for use as building thermal insulation. In most tropical developing countries, coconut and sugarcane fiber are byproducts of the coconut and sugarcane industries and these materials usually go to waste.

\section{Nomenclature}

$$
\begin{aligned}
& a=\text { constant } \\
& b=\text { constant } \\
& c=\text { constant } \\
& d=\text { constant } \\
& e=\text { constants } \\
& T=\text { Temperature, }{ }^{o} C, K
\end{aligned}
$$

Greek Symbols

$\lambda$ = apparent thermal conductivity, W/m.K

$\omega(T)=$ expression for temperature dependance

$\rho=$ density, $\mathrm{kg} / \mathrm{m}^{3}$

\section{Biodegradable Thermal Insulation}

The term biodegradable in this study refers to material that occur naturally in nature and when disposed off will decompose without causing any adverse effects on the environment. In this context by-products from the agricultural industry were considered. The waste material from the copra (coconut processing) industry showed a high degree of fibrous content. When shredded the resulting coconut fiber showed physical properties of fibers with a mean diameter of $0.267 \mathrm{~mm}$ with a range between $0.104 \mathrm{~mm}$ to

Paper accepted September, 2005. Technical Editor: Atila P. Silva Freire.
$0.502 \mathrm{~mm}$ and a standard deviation of $9.04 \times 10^{-2}$ (CARIRI project report, 1996). When arranged in a slab-like form as a thermal insulation batt the minimum density of coconut fiber without settling was $40 \mathrm{~kg} / \mathrm{m}^{3}$ (Kochhar and Manohar, 1997).

By products from the sugarcane industry were also looked at for use as thermal insulation. Sugarcane fiber (bagasse) consists of fibers of mean diameter $0.313 \mathrm{~mm}$ with a range between $0.156 \mathrm{~mm}$ to $0.504 \mathrm{~mm}$ and a standard deviation of $7.53 \times 10^{-2}$ (CARIRI project report, 1996). When arranged in a slab-like form as a thermal insulation batt the minimum density of sugarcane fiber without settling was $70 \mathrm{~kg} / \mathrm{m}^{3}$ (Kochhar and Manohar, 1997).

\section{Thermal Conductivity Measurement}

The thermal insulating properties of coconut fiber and sugarcane fiber were measured in accordance with ASTM C518 where the apparent thermal conductivity, $\lambda$, were measured under steady-state one-dimensional test conditions with heat flow upwards (Kochhar and Manohar, 1997). The test equipment used constant temperature plate $305 \mathrm{~mm}$ x $305 \mathrm{~mm}$ with a centrally located $102 \mathrm{~mm}$ x $102 \mathrm{~mm}$ heat flux transducers. The test equipment provided $\lambda$ measurements with $\pm 0.2 \%$ repeatability and $\pm 0.5 \%$ reproducibility within the range $0.005 \mathrm{~W} / \mathrm{m} . \mathrm{K}$ to $0.35 \mathrm{~W} / \mathrm{m} . \mathrm{K}$ (LaserComp FOX 304, 1994).

Thermal conductivity measurements were conducted on $52 \mathrm{~mm}$ thick, $254 \mathrm{~mm}$ square test specimens. The specimens were contained in a polystyrene specimen holder constructed from 25.4 $\mathrm{mm}$ thick polystyrene strips, $52 \mathrm{~mm}$ high. Coconut and sugarcane fiber samples were randomly selected from two respective stockpiles of air-dried material. The minimum test density for each material was determined by the lowest possible density for which the material existed under gravity without any appreciable settling. The clamping force between the constant temperature plates of the test equipment determined the upper test density limit.

For coconut fiber thermal conductivity tests were conducted at mean test temperatures of $15.6^{\circ} \mathrm{C}$ with a temperature difference of $16.3^{\circ} \mathrm{C}$ and $21.8^{\circ} \mathrm{C}$ with a temperature difference of $13.2^{\circ} \mathrm{C}$. For these test conditions three tests were conducted on each specimen of density $40 \mathrm{~kg} / \mathrm{m}^{3}, 50 \mathrm{~kg} / \mathrm{m}^{3}, 60 \mathrm{~kg} / \mathrm{m}^{3}, 70 \mathrm{~kg} / \mathrm{m}^{3}, 80 \mathrm{~kg} / \mathrm{m}^{3}$, and 90 $\mathrm{kg} / \mathrm{m}^{3}$. The mean values of the experimental test results for coconut fiber are shown on Table 1.

For sugarcane fiber thermal conductivity tests were conducted at mean test temperatures of $18^{\circ} \mathrm{C}, 24^{\circ} \mathrm{C}$ and $32^{\circ} \mathrm{C}$ with a temperature difference of $22^{\circ} \mathrm{C}$ in each case. For these test conditions three tests were conducted on each specimen of density $70 \mathrm{~kg} / \mathrm{m}^{3}, 80 \mathrm{~kg} / \mathrm{m}^{3}, 90$ $\mathrm{kg} / \mathrm{m}^{3}, 100 \mathrm{~kg} / \mathrm{m}^{3}, 110 \mathrm{~kg} / \mathrm{m}^{3}$, and $120 \mathrm{~kg} / \mathrm{m}^{3}$. The mean values of 
the experimental test results for sugarcane fiber are shown on Table 2.

Table 1. Experimentally determined $\lambda$ for coconut fiber.

\begin{tabular}{|l|l|l|}
\hline \multirow{2}{*}{ Density $\left(\mathrm{Kg} / \mathrm{m}^{3}\right)$} & \multicolumn{2}{|c|}{ Experimental $\lambda(\mathrm{W} / \mathrm{m} . \mathrm{K}) \pm 0.2 \%$} \\
\cline { 2 - 3 } & $15.6^{\circ} \mathrm{C}$ & $21.8^{\circ} \mathrm{C}$ \\
\hline 40 & 0.05624 & 0.05758 \\
\hline 50 & 0.05099 & 0.05184 \\
\hline 60 & 0.05051 & 0.04970 \\
\hline 70 & 0.04891 & 0.04884 \\
\hline 80 & 0.04800 & 0.04886 \\
\hline 90 & 0.04869 & 0.05009 \\
\hline
\end{tabular}

Table 2. Experimentally determined $\lambda$ for sugarcane fiber.

\begin{tabular}{|l|l|l|l|}
\hline \multirow{2}{*}{ Density $\left(\mathrm{Kg} / \mathrm{m}^{3}\right)$} & \multicolumn{3}{|l|}{ Experimental $\lambda(\mathrm{W} / \mathrm{m} . \mathrm{K}) \pm 0.2 \%$} \\
\cline { 2 - 4 } & $18^{\circ} \mathrm{C}$ & $24^{\circ} \mathrm{C}$ & $32^{\circ} \mathrm{C}$ \\
\hline 70 & 0.04977 & 0.05094 & 0.05314 \\
\hline 80 & 0.04851 & 0.04966 & 0.05060 \\
\hline 90 & 0.04851 & 0.04896 & 0.04947 \\
\hline 100 & 0.04610 & 0.04680 & 0.04862 \\
\hline 110 & 0.04909 & 0.04992 & 0.04963 \\
\hline 120 & 0.04888 & 0.04964 & 0.05099 \\
\hline
\end{tabular}

The experimental results for both coconut and sugarcane fibers indicated the general trend associated with loose-fill thermal insulation (Bankvall, 1973; Pratt, 1978). That is, as density increases from the minimum possible value upwards, $\lambda$ decreases to a minimum and then increases. Therefore, the $\lambda$ variation with density should satisfy the general empirical relationship associated with this characteristic behavior of materials of this nature as given in Eq.(1) (Bankvall, 1974).

$$
\lambda=a+b \rho+c / \rho
$$

Using the Method of Least Squares, the experimental data for coconut fiber and sugarcane fiber for each test condition were fitted in the form of Equation (1) and the empirical constants were determined. The resulting equations are as follows:

Coconut Fiber $15.6^{\circ} \mathrm{C}$ mean test temperature;

$$
\lambda=0.19236 \times 10^{-1}+0.18031 \times 10^{-3} \rho+1.1812 / \rho
$$

Coconut Fiber $21.8^{\circ} \mathrm{C}$ mean test temperature;

$$
\lambda=-0.14291 \times 10^{-2}+0.34979 \times 10^{-3} \rho+1.1812 / \rho
$$

Sugarcane Fiber $18^{\circ} \mathrm{C}$ mean test temperature;

$$
\lambda=-0.21107 \times 10^{-2}+0.26227 \times 10^{-3} \rho+2.3580 / \rho
$$

Sugarcane Fiber $24^{\circ} \mathrm{C}$ mean test temperature;

$$
\lambda=-0.99910 \times 10^{-2}+0.30485 \times 10^{-3} \rho+2.7878 / \rho
$$

Sugarcane Fiber $32^{\circ} \mathrm{C}$ mean test temperature;

$$
\lambda=-0.31685 \times 10^{-1}+0.41687 \times 10^{-3} \rho+3.9030 / \rho
$$

Another characteristic feature of lose-fill insulation is an increase of $\lambda$ with mean test temperature (Manohar, Yarbrough and Kochhar, 2000). In general, the experimental results for both coconut fiber and sugarcane fiber showed linearly increasing $\lambda$ with temperature. In order to determine $\lambda$ variation with mean test temperature, the respective coefficients of $a, b$, and $c$, from the isothermal equations for both coconut and sugarcane fiber were fitted to a relationship of the general form;

$$
\omega(T)=d+e . T
$$

where $\omega(T)$ is an expression for temperature dependance, $d$ and $e$ are constants, and $\mathrm{T}$ is the temperature. This resulted in general empirical relationships for determining $\lambda$ in terms of temperature and specimen density for coconut and sugarcane fiber.

Coconut Fiber:

$$
\begin{gathered}
\lambda=(0.071232-0.003333 T)+\left(-0.000246+2.73355 \times 10^{-5} T\right) \rho \\
+(-0.372006+0.099565 T) / \rho
\end{gathered}
$$

Sugarcane Fiber:

$$
\begin{gathered}
\lambda=\left(0.38311 \times 10^{-1}-0.21448 \times 10^{-2} T\right) \\
+\left(0.51660 \times 10^{-4}+0.11203 \times 10^{-4} T\right) \rho \\
+(0.25540+0.11193 T) / \rho
\end{gathered}
$$

\section{Comparison of Thermal Conductivity Data}

The general empirical relationships from equations (8) and (9) were used to calculate the apparent thermal conductivity for coconut and sugarcane fiber, respectively, at a mean test temperature of $24^{\circ} \mathrm{C}$. Thermal conductivity values were determined for the respective test densities and are given on Tables 3 and 4.

Table 3. Theoretical apparent thermal conductivity of coconut fiber at 24 ${ }^{\circ} \mathrm{C}$ from Eq. (8)

\begin{tabular}{|l|l|}
\hline Density $\left(\mathrm{kg} / \mathrm{m}^{3}\right)$ & Thermal Conductivity, $\lambda(\mathrm{W} / \mathrm{m} . \mathrm{K})$ \\
\hline 40 & 0.05808 \\
\hline 50 & 0.05209 \\
\hline 60 & 0.04947 \\
\hline 70 & 0.04877 \\
\hline 80 & 0.04926 \\
\hline 90 & 0.05056 \\
\hline
\end{tabular}

This data was compared with published results for kapok, jute (Stephenson and Mark, 1961), glass fiber (Battacharyya, 1980), airfilled foam (Glicksman, 1994), molded polystyrene, cellulose, and rock wool (Tye et al., 1980). A graphical interpretation of the results is shown in Figure 1.

Table 4. Theoretical apparent thermal conductivity of sugarcane fiber at $24{ }^{\circ} \mathrm{C}$ from Eq. (9).

\begin{tabular}{|l|l|}
\hline Density $\left(\mathrm{kg} / \mathrm{m}^{3}\right)$ & Thermal Conductivity, $\lambda(\mathrm{W} / \mathrm{m} . \mathrm{K})$ \\
\hline 70 & 0.05130 \\
\hline 80 & 0.04925 \\
\hline 90 & 0.04837 \\
\hline 100 & 0.04831 \\
\hline 110 & 0.04884 \\
\hline 120 & 0.04981 \\
\hline
\end{tabular}




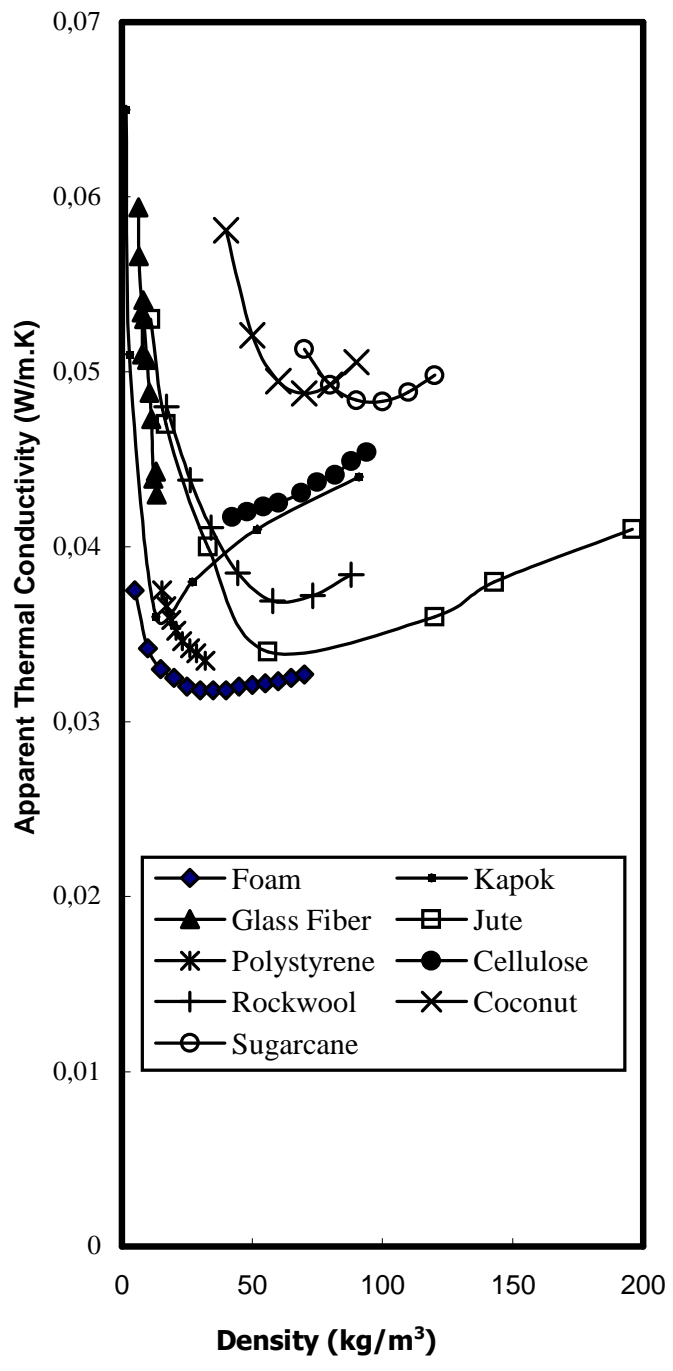

Figure 1. Comparative apparent thermal conductivity data for nine insulations.

\section{Discussion}

Experimental data at various mean test temperatures show the thermal conductivity variation with density for coconut fiber and sugarcane fiber followed the characteristic hooked shape associated with loose-fill fibrous insulation. The $\lambda$ variation with density for coconut fiber showed the minimum $\lambda$ value at a density of $80 \mathrm{~kg} / \mathrm{m}^{3}$ for experiments conducted at mean test temperatures of $15.6^{\circ} \mathrm{C}$ and $21.8^{\circ} \mathrm{C}$. For sugarcane fiber the minimum $\lambda$ value occurred at a density of $100 \mathrm{~kg} / \mathrm{m}^{3}$ for tests conducted at mean temperatures of $18^{\circ} \mathrm{C}, 24^{\circ} \mathrm{C}$ and $32^{\circ} \mathrm{C}$. For both material the minimum $\lambda$ showed an increase with mean test temperature which is consistent with the behavior of loose-fill thermal insulation (Pratt, 1978). The empirical relationships for the $\lambda$ variation with temperature and density for coconut and sugarcane fiber indicated behavior consistent with loose-fill insulating materials.

The minimum $\lambda$ for coconut and sugarcane fiber ranged between $0.048 \mathrm{~W} / \mathrm{m} . \mathrm{K}$ to $0.049 \mathrm{~W} / \mathrm{m} . \mathrm{K}$ and $0.046 \mathrm{~W} / \mathrm{m} . \mathrm{K}$ to $0.049 \mathrm{~W} / \mathrm{m} . \mathrm{K}$ over the temperature ranges $15.6^{\circ} \mathrm{C}$ to $21.8^{\circ} \mathrm{C}$ and $18^{\circ} \mathrm{C}$ to $32^{\circ} \mathrm{C}$, respectively. Comparison of the minimum $\lambda$ of coconut and sugarcane fiber with different loose-fill materials from Figure 1 showed a $\lambda$ difference ranging from $0.006 \mathrm{~W} / \mathrm{m} . \mathrm{K}$ with cellulose to $0.014 \mathrm{~W} / \mathrm{m} . \mathrm{K}$ with jute. Comparison of the minimum $\lambda$ with the closed cell materials from Figure 1 showed a $\lambda$ difference ranging from $0.014 \mathrm{~W} / \mathrm{m} . \mathrm{K}$ with molded polystyrene to $0.016 \mathrm{~W} / \mathrm{m} . \mathrm{K}$ with air-filled foam.

From the seven comparative insulation materials listed the percentage difference in $\lambda$ ranged from $12.5 \%$ to $33 \%$ which indicated that coconut and sugarcane fiber are within the range of materials normally used for building thermal insulation.

These naturally occurring materials have the advantage of being environmentally friendly (biodegradable). However, consideration has to be given to the flammability of the materials and the higher density at which $\lambda$ is minimum. Also, susceptibility to insect attack and fungal growth over long time periods need to be investigated.

\section{Conclusions}

Coconut fiber and sugarcane fiber have acceptable $\lambda$ values for use as building thermal insulation.

The optimum $\lambda$ values at $24^{\circ} \mathrm{C}$ averaged about $0.0488 \mathrm{~W} / \mathrm{m} . \mathrm{K}$ and $0.0483 \mathrm{~W} / \mathrm{m} . \mathrm{K}$ for coconut and sugarcane fiber, respectively.

The $\lambda$ of both coconut and sugarcane fiber increased with temperature within the test range of $15.6^{\circ} \mathrm{C}$ to $32^{\circ} \mathrm{C}$. This behavior is consistent with loose fill insulating material.

Both coconut and sugarcane fiber exhibited the hooked shape graph of thermal conductivity with density. This behavior is consistent with loose fill insulating material.

Both materials have the advantage of being environmentally friendly (biodegradable).

\section{References}

Bankvall, C., 1973, "Heat Transmission in Fibrous Materials," Journal of Testing and Evaluation, Vol. 1, No. 3, pp. 235-243.

Bankvall, C., 1974, "Mechanism of Heat Transfer in Permiable Insulation and their Investigation in a Special Guarded Hot Plate," Heat Transmission Measurements in Thermal Insulation, American Society for Testing and Materials, ASTM STP 544, pp. 34-38.

Bhattacharyya, R. K., 1980, "Heat Transfer Model for Fibrous Insulations," Thermal Insulation Performance, ASTM STP 718, D. L. McElroy and R. P. Tye, Eds., American Society for Testing and Materials, pp. 272-286.

CARIRI Service Project Report, 1996, "Investigation of Sugarcane and Coconut Fiber'. Tunapuna, Trinidad and Tobago: Caribbean Industrial Research Institute; Report No. 794/796.

Glicksman, L. R., 1994, "Heat Transfer in Foams," Low Density Cellular Plastics; Physical Basis of Behavior, N. C. Hilyard and A. Cunningham, Eds., pp. 104-152.

Kochhar, G. S., and Manohar, K., 1997, "Use of Coconut Fiber as a Low-Cost Thermal Insulator," Insulation Materials: Testing and Applications: Third Volume, ASTM STP 1320, R. S. Graves and R. R. Zarr, Eds., American Society for Testing and Materials, pp. 283-291.

LaserComp FOX 304, 1994, "Heat Flow Meter Thermal Conductivity Instrument," Information Sheet, LaserComp; Wakefield, MA, USA.

Manohar, K., Yarbrough, D. W., and Kochhar, G. S., 2000, "Building Thermal Insulation - Biodegradable Sugarcane and Coconut Fiber," Journal of Thermal Envelope and Building Science, Vol. 23, No. 3, pp. 263-276.

Pratt, A. W., 1978, Heat Transmission in Buildings, John Wiley and Sons - Interscience Publication, London, pp. 31-42.

Stephenson, M. E., and Mark, M., 1961, "Thermal Conductivity of Porous Materials," ASHRAE Journal, Vol. 1, pp. 75-81.

Tye, R. P., Ashars, E., Guyer, E. C., and Sharon, A. C., 1980, "An Assessment of Thermal Insulation Materials for Building Applications," Thermal Insulation Performance, ASTM STP 718, D. L. McElroy and R. P. Tye, Eds., American Society for Testing and Materials, pp. 9-26. 